\title{
Analisis Kemampuan Penalaran Matematika Siswa SMA pada Materi Geometri Ruang
}

\author{
Muslimin', Sunardi²
}

\author{
1,2Universitas Muhammadiyah Palembang
}

Corresponding Author: muslim_ump@yahoo.com,,sunardi_hek@yahoo.co.id²

DOI: http://dx.doi.org/10.15294/kreano.v10i2.18323

Received : February 2 2019; Accepted: December 2 2019; Published: December 42019

\begin{abstract}
Abstrak
Penelitian ini dilatarbelakangi oleh rendahnya kemampuan penalaran matematika siswa Sekolah Menengah Atas (SMA) dalam matematika. Siswa mengalami kesulitan dalam pembelajaran materi geometri ruang. Penelitian ini bertujuan untuk mengetahui gambaran kemampuan penalaran matematika siswa SMA pada materi geometri ruang. Metode penelitian ini adalah kualitatif deskriptif dengan menganalisis kemampuan penalaran siswa dari instrumen yang diberikan. Instrumen dalam penelitian ini berbentuk tes tertulis yang berjumlah 5 soal. Berdasarkan hasil penelitian penelitian di SMAYPITunas Bangsa Palembang diperoleh nilai rata-rata kemampuan penalaran matematika siswa sebesar 66,11 yang tergolong cukup. Secara keseluruhan, indikator kemampuan penalaran matematika yang banyak dikuasai siswa adalah menyajikan pernyataan matematika dengan gambar dan tulisan, sedangkan indikator kemampuan penalaran matematika yang kurang dikuasai siswa adalah menarik kesimpulan dari suatu pernyataan.
\end{abstract}

\begin{abstract}
This research is motivated by the low mathematical reasoning abilities of high school students in mathematics. Students experience difficulties in learning space geometry material. This study aims to describe the mathematical reasoning abilities of high school students in space geometry. The method of this research is descriptive qualitative by analyzing the students' reasoning abilities of the given instrument. The instruments in this study were in the form of written tests totaling 5 questions. Based on the results of research at Tunas Bangsa Palembang YPI High School, the average mathematical reasoning ability of students of 66.11 was obtained as an average. Overall, the indicator of mathematical reasoning abilities that are controlled by many students is presenting mathematical statements with images and writing, while indicators of mathematical reasoning abilities that are less mastered by students are drawing conclusions from a statement.
\end{abstract}

Keywords: reasoning ability; space geometry

\section{PENDAHULUAN}

Pendidikan matematika di Indonesia berkembang sejalan dengan perkembangan pendidikan matematika dunia. Perubahanperubahan yang terjadi dalam proses pembelajaran di kelas, selain dipengaruhi adanya tuntutan sesuai perkembangan teknologi dan ilmu pengetahuan juga seringkali diawali adanya perubahan pandangan tentang hakekat matematika serta pembelajarannya. Perubahan pandangan tentang hakekat matema- tika dapat mendorong terjadinya perubahan substansi kurikulum. Sementara itu perubahan pandangan tentang pembelajaran matematika sangat dipengaruhi oleh terjadinya perkembangan mengenai teori belajar baik yang bersifat umum maupun yang khusus berkaitan dengan belajar matematika. Walaupun perubahan pembelajaran matematika saat ini terjadi secara pelan-pelan, akan tetapi upayaupaya untuk memperbaiki kualitasnya sesuai perkembangan yang terjadi di dunia mulai 
dilakukan sekalipun masih bersifat terbatas. (Suryadi, 2011)

Penalaran mulai ditonjolkan dalam kurikulum matematika di seluruh dunia dan dipandang sebagai upaya utama untuk mereformasi pembelajaran matematika (Safrida, As'ari, \& Sisworo, 2016). Penalaran dan matematika merupakan satu kesatuan yang tidak dapat dipisahkan karena materi matematika dipahami melalui penalaran. Upaya peningkatan kemampuan penalaran matematis siswa dapat dilakukan dengan memberikan tugas yang tidak rutin. Kemampuan penalaran matematis salah satu tujuan dari pembelajaran matematika (Anisa, 2014). Penalaran matematis merupakan suatu kebiasaan otak yang apabila dikembangkan dengan baik dan konsisten akan memudahkan dalam mengkomunikasikan matematis baik secara tertulis maupun lisan. Ada 4 indikator bahwa seorang siswa melakukan penalaran, yaitu siswa: (a) Membuat kesimpulan logis; (b) Memberikan penjelasan tentang model, fakta, properti, hubungan, atau pola yang ada; (c) Membuat dugaan dan bukti; dan (d) Menggunakan pola hubungan untuk menganalisa situasi, membuat analogi, atau menggeneralisasikan ( $\mathrm{Na}$ pitupulu et al, 2016).

Menurut hasil survey IMSTEP-JICA (Herman, 2007) rendahnya pemahaman siswa dalam matematika salah satunya disebabkan oleh pembelajaran matematika yang terlalu berkonsentrasi pada hal-hal yang prosedural dan mekanistik, pembelajaran berpusat pada guru, konsep matematika disampaikan secara informatif, dan siswa dilatih menyelesaikan banyak soal tanpa pemahaman yang mendalam. Akibatnya, kemampuan penalaran dan kompetensi strategis siswa tidak berkembang sebagaimana mestinya. Kemampuan penalaran menjadi salah satu tujuan dalam pembelajaran matematika di sekolah yaitu melatih cara berpikir dan bernalar dalam menarik kesimpulan, mengembangkan kemampuan memecahkan masalah, serta mengembangkan kemampuan menyampaikan informasi atau mengkomunikasikan ide-ide melalui lisan, tulisan, gambar, grafik, peta, diagram, dan sebagainya (Depdiknas, 2006).

Di Matematika, seluruh materi sebenarnya bisa digunakan untuk mengukur kemam- puan penalaran. Namun, geometri tampaknya paling relevan dipilih karena sifat materinya yang khas. Geometri adalah cabang matematika yang diajarkan dengan tujuan agar siswa dapat memahami sifat-sifat dan hubungan antar unsur geometri serta dapat menjadi pemecah masalah yang baik. Masih banyak siswa yang mengalami kesulitan dalam belajar geometri. Salah satu penyebab sulitnya siswa dalam memahami geometri adalah strategi pembelajaran yang digunakan tidak sesuai dengan materi yang diajarkan. Selain itu, dalam pembelajaran geometri selama ini belum disesuaikan dengan tingkat perkembangan berpikir siswa. Oleh karena itu diperlukan strategi yang tepat yang disusun berdasarkan tingkat perkembangan berpikir siswa dalam geometri (Safrina, 2014).

Pada pembelajaran geometri ditemukan bahwa siswa mengalami kesulitan dalam belajar. Siswa mengalami kegagalan dalam memahami konsep-konsep kunci dalam geometri dan belajar geometri tanpa memahami terminologi dasar. Hal serupa juga diungkapkan oleh Burger dan Shaughnessy (1986) yang menyatakan bahwa siswa memiliki kesulitan dalam mengidentifkasi gambar dan kesulitan pada masalah pembuktian suatu teorema pada bangun dalam pembelajarn geometri. Selanjutnya, survey dari Programme for International Students Assessment (PISA) (2000) mengungkapkan bahwa siswa masih lemah dalam geometri, lebih khusus dalam pemahaman ruang dan bentuk. (Sulistiawati, Suryadi, \& Fatimah, 2016)

Demikian pula halnya dengan hasil survey Programme for International Students Assesment (PISA, 2012)the United States performed below average in mathematics in 2012 and is ranked 27 th (this is the best estimate, although the rank could be between 23 and 29 due to sampling and measurement error yang menunjukkan bahwa siswa lemah dalam geometri, khususnya dalam pemahaman ruang dan bentuk. Penelitian bermaksud untuk mengetahui kesulitan-kesulitan yang mungkin dialami oleh siswa dalam pembelajaran geometri ruang khususnya untuk materi titik, garis, bidang, jarak dan sudut yang berkaitan dengan kemampuan penalaran matematis siswa. 


\section{METODE}

Penelitian ini dilakukan pada semester ganjil tahun akademik 2018/2019. Subjek penelitian adalah kelas XII IPA 3 SMA YPI Tunas Bangsa Palembang yang berjumlah 30 siswa. Penelitian ini termasuk ke dalam penelitian deskriptif yang bertujuan untuk mendeskripsikan gambaran kemampuan penalaran matematika siswa SMA pada materi geometri ruang. Variabel dalam penelitian ini adalah kemampuan penalaran matematika siswa SMA. Kemampuan penalaran matematika dalam penelitian ini meliputi kemampuan menyajikan pernyataan matematika secara lisan, tertulis, gambar, dan diagram, kemampuan melakukan manipulasi matematika, kemampuan menyusun bukti, memberikan alasan atau bukti terhadap beberapa solusi, dan kemampuan menarik kesimpulan dari pernyataan. Kemampuan tersebut dilihat dari nilai yang diperoleh siswa dalam menyelesaikan soal-soal geometri ruang yang berbentuk soal uraian berjumlah sepuluh soal.

Prosedur dalam penelitian ini yaitu meliputi pengurusan surat perizinan di sekolah yang akan diteliti, pemilihan soal-soal geometri ruang dan membuat pilihan jawaban yang ada di dalam soal, karena soal yang diujikan berbentuk soal uraian. Kemudian dalam proses pengambilan data, peneliti memberikan langsung instrumen berupa soal-soal materi geometri ruang kepada siswa yang akan diteliti.

Teknik pengumpulan data dalam penelitian yaitu berupa tes tertulis yang bertujuan untuk mengetahui gambaran kemampuan penalaran matematika siswa SMA pada materi geometri ruang dengan memberikan sejumlah 5 soal. Tes ini dikerjakan siswa secara individu. Soal disesuaikan dengan indikator kemampuan penalaran matematika. Selanjutnya teknik analisis data dalam penelitian ini yaitu berupa analisis data tes yang mengacu pedoman rubrik penskoran dan memeriksa skor masing-masing jawaban soal. Adapun pedoman penskoran yang digunakan dapat dilihat pada Tabel 1.
Tabel 1. Rubrik Penskoran Soal Penalaran

\begin{tabular}{|c|c|}
\hline Skor & Indikator Penskoran \\
\hline 4 & $\begin{array}{l}\text { Jawaban sempurna dan terlihat semua } \\
\text { indikator penalaran secara sistematis dan } \\
\text { benar }\end{array}$ \\
\hline 3 & $\begin{array}{l}\text { Jawaban benar, tetapi hanya terlihat be- } \\
\text { berapa dari indikator penalaran yang di- } \\
\text { ingikan soal. }\end{array}$ \\
\hline 2 & $\begin{array}{l}\text { Jawaban benar secara parsial dan men- } \\
\text { gandung lebih dari satu indikator penal- } \\
\text { aran yang diinginkan soal. }\end{array}$ \\
\hline 1 & $\begin{array}{l}\text { Jawaban salah, respon (penyelesaian) ti- } \\
\text { dak terselesaikan secara keseluruhan na- } \\
\text { mun mengandung sekurang-kurangnya } \\
\text { satu indikator penalaran yang benar }\end{array}$ \\
\hline 0 & $\begin{array}{l}\text { Jawaban salah, respon (penyelesain) di- } \\
\text { dasarkan pada proses atau yang salah } \\
\text { atau tidak mengandung indikator penal- } \\
\text { aran sama sekali. }\end{array}$ \\
\hline
\end{tabular}

\section{HASIL DAN PEMBAHASAN}

\section{Hasil Penelitian}

Setelah dilakukan penyekoran, diperoleh nilai tes yang kemudian di konversi ke nilai kualitatif berdasarkan kategori ketinggiannya. Hasil akhir nilai kemampuan penalaran siswa SMA dapat dilihat pada Tabel 2.

Tabel 2. Nilai Kemampuan Penalaran Matematika Siswa SMA

\begin{tabular}{cccc}
\hline $\begin{array}{c}\text { Nilai } \\
\text { Siswa }\end{array}$ & Kategori & Frekuensi & Persentase \\
\hline $86-100$ & Sangat Tinggi & 1 & $2 \%$ \\
$71-85$ & Tinggi & 14 & $31 \%$ \\
$56-70$ & Cukup & 21 & $47 \%$ \\
$41-55$ & Rendah & 7 & $16 \%$ \\
0-40 & Sangat Ren- & 2 & $4 \%$ \\
\hline \multicolumn{4}{c}{ Jum } \\
\hline Jumlah Siswa & 45 & $100 \%$ \\
\hline \multicolumn{3}{c}{ Nilai Rata-rata } & 66,11 \\
\hline
\end{tabular}

Berdasarkan Tabel 2, dapat dilihat bahwa nilai rata-rata yang diperoleh siswa untuk tes kemampuan penalaran ini adalah 66,11, ini menunjukkan kemampuan penalaran matematika siswa SMA tergolong cukup.

Data mengenai kemampuan penalaran siswa diperoleh dari hasil tes pada soal materi geometri ruang. Soal yang diberikan berjumlah 5 soal uraian yang dikerjakan se- 
cara individu dalam waktu 40 menit, jumlah siswa yang mengikuti tes yaitu 45 siswa. Penyekoran yang dilakukan mengacu pada rubrik penyekoran, yaitu skor 4 untuk jawaban sempurna, terlihat semua indikator penalaran secara sistematis dan benar, skor 3 untuk jawaban benar, tetapi hanya terlihat beberapa dari indikator penalaran yang diingikan soal, skor 2 untuk jawaban benar secara parsial, namun mengandung lebih dari satu indikator penalaran yang diinginkan soal, skor 1 untuk jawaban Jawaban salah, respon (penyelesaian) tidak terselesaikan secara keseluruhan namun mengandung sekurang-kurangnya satu indikator penalaran yang benar, dan skor o untuk jawaban salah, respon (penyelesain) didasarkan pada proses atau yang salah atau tidak mengandung indikator penalaran sama sekali. Gambar 1 merupakan beberapa contoh penyelesaian siswa pada soal nomor 3 dan skor yang diperoleh oleh siswa.
Pada gambar 1 siswa dapat menyelesaikan soal secara lengkap dan benar, dan 4 indikator kemampuan penalaran muncul pada jawaban siswa.

Pada Gambar 2 siswa mampu menjawab dengan benar, akan tetapi salah satu indikator kemampuan penalaran menarik kesimpulan dari suatu pernyataan tidak muncul pada jawaban siswa. Siswa menjawab soal tanpa menggunakan satuan yang benar. Siswa berkarakter demikian cenderung memiliki kemampuan berpikir numerik yang lebih tinggi dari pada penalaran (Indrawati, 2015). Pada awalnya, seorang pembelajar matematika akan cenderung memilih berhitung. Hal ini karena berhitung, yang merupakan wujud dari kecerdasan numeric tidak memerlukan proses berpikir tingkat tinggi. Namun, pengalaman dan latihan yang intensif akan mendorong siswa untuk berpikir menalar (Irawan, 2015).

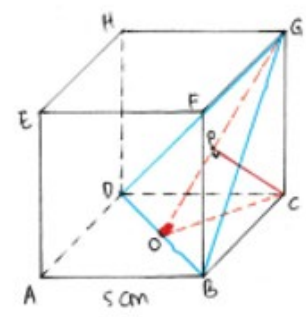

$$
\begin{aligned}
& B D=D G=G B=5 \sqrt{2} \mathrm{~cm} \\
& G O=\sqrt{B G^{2}-B O^{2}} \\
& =\sqrt{(5 \sqrt{2})^{1}-\left(\frac{c}{2} \sqrt{2}\right)^{2}} \\
& =\sqrt{25 \cdot 2-\frac{25}{4} \cdot 2} \\
& =\sqrt{50-\frac{50}{4}} \\
& =\sqrt{\frac{200-50}{4}} \\
& -\sqrt{\frac{50}{4}} \\
& =\frac{5}{2} \sqrt{6} \mathrm{~cm}
\end{aligned}
$$

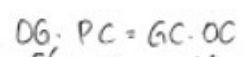

Gambar 1. Jawaban siswa skor 4
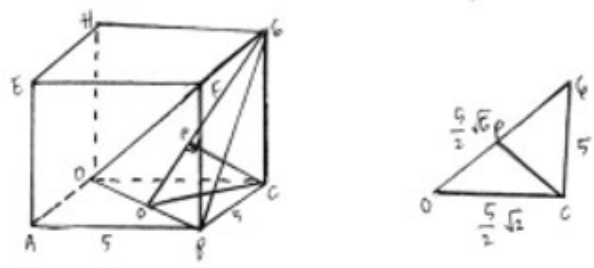

$$
\begin{aligned}
& \frac{529 \sqrt{2}}{5 \sqrt{6}}=x \\
& \frac{5 \sqrt{2}}{\sqrt{6}} \cdot \frac{\sqrt{6}}{\sqrt{6}}=x \\
& x=\frac{5 \sqrt{12}}{6} \\
& x=\frac{10}{6} \sqrt{3} \\
& x=\frac{5}{3} \sqrt{3} \mathrm{~cm} .
\end{aligned}
$$

Gambar 2. Jawaban siswa skor 3 


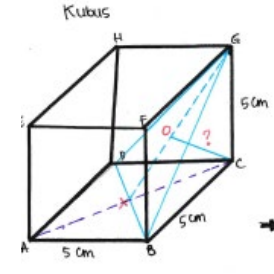

Jarak $C$ ke BOA?

Jawab:

$A C=5 \sqrt{2} \mathrm{~cm}$

$C X=1 / 2 \cdot A C=1 / 2 \cdot 5 \sqrt{2}=\frac{5}{2} \sqrt{2} \mathrm{~cm}$

$G C=5 \mathrm{~cm}$

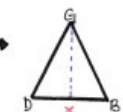

$G B=G D=D B=5 \sqrt{2} \mathrm{~cm}$

$G X=\frac{G D \cdot G B}{D B}=\frac{5 \sqrt{2} \cdot 5 \sqrt{2}}{5 / 2}=5 \sqrt{2} \mathrm{~cm}$
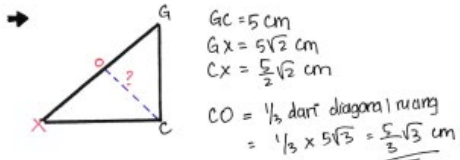

Gambar 3. Jawaban siswa skor 2

Pada gambar 3 siswa menjawab benar secara parsial, namun respon (penyelesaian) yang diberikan mengandung dua indikator kemampuan penalaran. Siswa melakukan kesalahan dalam memanipulasi soal. Akibatnya siswa tidak mampu menyelesaikan soal secara tepat, walaupun sebenarnya siswa telah mampu memperoleh hasil perhitungannya, namun siswa mengalami kesalahan dalam memberikan satuan dalam menyimpulkan hasil jawaban. Dalam konteks penalaran, siswa tersebut masih termasuk dalam level penalaran impulsif (Septianingsih dan Fitriyani, 2018). Subjek siswa tersebut baru bisa menyampaikan informasi berdasarkan fakta yang tampak. Subjek belum bisa menyelesaikan permasalahan jika masih tersirat.

Pada gambar 4 dapat dilihat bahwa jawaban salah, soal yang dikerjakan oleh siswa tidak terselesaikan secara keseluruhan namun mengandung beberapa argumen yang benar yang merupakan indikator dari kemampuan penalaran. Siswa mampu menyatakan soal dalam sebuah gambar serta tulisan, siswa mampu memanipulasi data pada soal. Siswa dengan model berpikir yang demikian cenderung tergesa dalam bertindak. Dalam konteks penalaran, model berpikir yang demikian masuk ke dalam kategori berpikir impulsive awal (Shodiqin dan Zuhri, 2018)
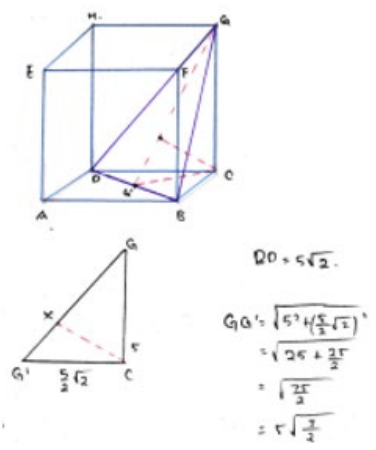

$$
\begin{aligned}
& \frac{1}{2} \cdot C G^{\prime} \cdot G C \cdot \frac{1}{2} \cdot G \times \cdot C x \\
& \frac{1}{2} \cdot \frac{5}{2} \sqrt{2} \cdot 5=\frac{1}{2} \cdot \frac{10}{3} \sqrt{\frac{3}{2}} \cdot c x \\
& C x=\frac{\frac{25}{2} \sqrt{2}}{\frac{10}{3} \sqrt{\frac{1}{2}}} \\
& C_{x}=\frac{5}{25} \sqrt{2} \cdot \frac{3}{10} \sqrt{\frac{2}{2}} \\
& C_{*}=\frac{15 \sqrt{2}}{4 \sqrt{\frac{3}{2}}} \cdot \frac{4 \sqrt{\frac{3}{2}}}{4 \sqrt{\frac{2}{2}}} \\
& C x=\frac{60 \sqrt{3}}{816 \cdot \frac{3}{8}} \\
& C_{x}=\frac{\infty}{24} \sqrt{3} \text {. } \\
& C_{x}=\frac{10}{4} \sqrt{3} \\
& c_{x}=\frac{5}{2} \sqrt{3}
\end{aligned}
$$

Gambar 4. Jawaban siswa skor 1

Pada gambar 5 dapat dilihat bahwa jawaban siswa didasarkan pada proses atau argumen yang salah, siswa tidak memahami materi geometri ruang sehingga indikator kemampuan penalaran tidak muncul dalam jawaban siswa.

Berdasarkan hasil tes dapat dilihat bahwa rata-rata kemampuan penalaran matematika siswa SMA adalah 66,11 yang tergolong cukup. Dari 5 soal yang diberikan, nomor soal yang paling banyak dijawab benar (skor 4) adalah soal nomor 1 dan nomor 4, masingmasing sebanyak 43 siswa. Sebanyak 28 siswa menjawab benar pada soal nomor 2, sebanyak 28 siswa yang menjawab benar pada soal nomor 2. Sedangkan untuk soal nomor 3 dan
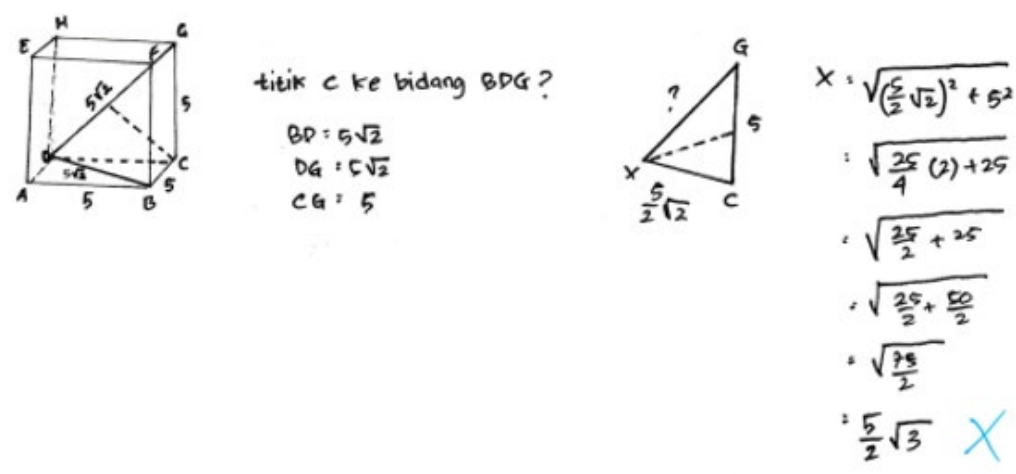

Gambar 5. Jawaban siswa skor o 
nomor 5 ada 31 siswa dan 41 siswa yang menjawab benar.

Soal nomor 1: Diketahui kubus ABCD.EFGH dengan panjang rusuk $2 \mathrm{~cm}$. Titik $M$ adalah titik potong garis $A C$ dan garis $B D$. Tentukan jarak antara titik H dan titik M! Berikut ini merupakan beberapa jawaban siswa untuk soal nomor satu.

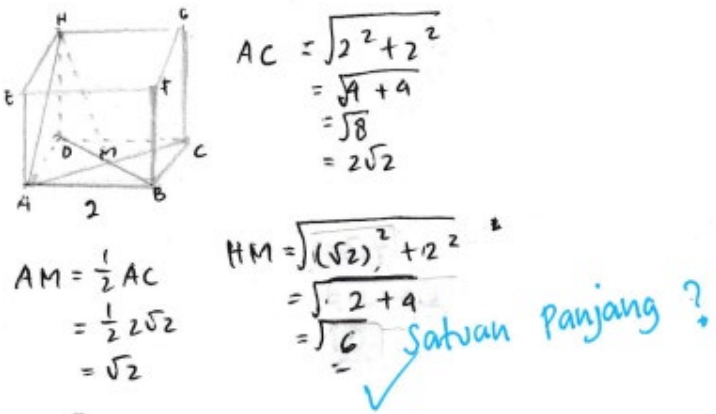

Gambar 6. Jawaban siswa soal nomor 1

Pada gambar 6 dapat dilihat bahwa siswa belum mampu menyatakan soal ke dalam bentuk gambar secara benar, siswa juga belum mampu memanipulasi soal ke dalam bentuk rumus yang digunakan untuk menyelesaikan masalah dalam soal. Kemudian siswa tidak memberikan satuan yang benar pada hasil akhir jawaban. Kesalahan ini menunjukkan bahwa siswa tidak mampu membuat kesimpulan secara benar. Terutama pada bagian manipulasi matematika (Sulistiawati et al, 2016). Akan tetapi apabila dilihat secara keseluruhan, hanya ada beberapa siswa yang melakukan kesalahan dalam menyimpulkan hasil akhir jawaban.

Soal nomor 2: Diketahui limas beraturan $T . A B C D$, panjang rusuk $A B=3 \mathrm{~cm}$ dan $T A=6$ $\mathrm{cm}$. Tentukan jarak titik $B$ dan garis TD! Berikut ini merupakan beberapa jawaban siswa untuk soal nomor dua.

Pada gambar 7 siswa mampu menyajikan pernyataan matematika secara tertulis dan gambar, siswa mampu menyatakan kalimat pada soal ke dalam simbol matematika, panjang $D B=$ dan panjang $D O=$. Selanjutnya siswa tidak melakukan suatu memanipulsi soal ke dalam bentuk rumus yang gunakan, namun siswa mampu menyusun bukti-bukti dalam menyelesaikan dengan tepat soal diberikan.
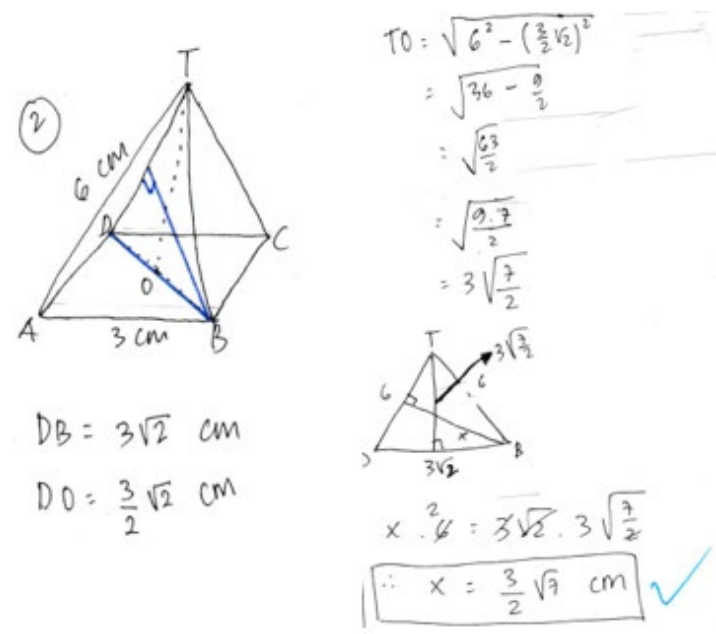

Gambar 7. Jawaban siswa soal nomor 2

Pada soal nomor 2 , sebanyak 28 orang siswa menjawab dengan tepat soal yang diberikan. Siswa mendapat skor sempurna, yaitu sebanyak 2 siswa. Dikatakan mendapat skor sempurna karena mampu memunculkan indikator kemampuan penalaran yang terdapat pada soal yaitu menyajikan pernyataan matematika secara gambar maupun, menyatakan dugaan, melakukan manipulasi matematika, menyusun bukti, dan menarik kesimpulan dari pernyataan. Apabila dibandingkan dengan soal-soal lain, siswa paling banyak melakukan kesalahan pada soal ini.

Soal nomor 3: Diketahui kubus ABCD.EFGH dengan panjang rusuk $5 \mathrm{~cm}$. Tentukan jarak antara titik C ke bidang BDG! Berikut ini merupakan beberapa jawaban siswa untuk soal nomor tiga:

Pada gambar 8 dapat dilihat bahwa siswa mampu menyajikan pernyataan matematika ke dalam bentuk gambar, hal ini terlihat pada saat siswa mengambar kubus dengan benar serta menduga rumus yang digunakan dalam menyelesaikan soal tersebut. Pada gambar 8 tersebut siswa tidak melakukan manipulasi matematika, hal itu dikarenakan siswa lupa menuliskan rumus yang digunakan untuk menyelesaikan soal nomor 3, akibatnya siswa mengalami kesulitan dalam melakukan manipulasi matematika. Kemudian siswa ti- 


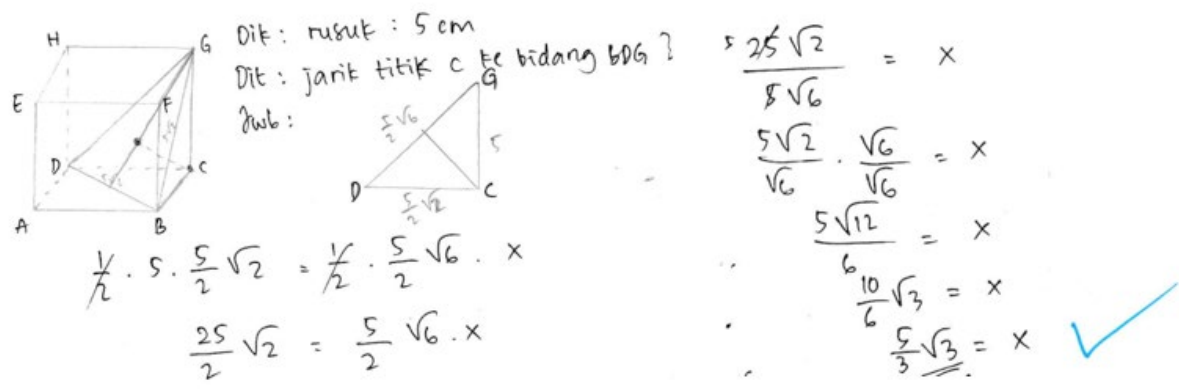

Gambar 8. Jawaban siswa soal nomor 3

dak menyimpulkan hasil jawabannya dengan benar, siswa lupa menuliskan satuan panjang yang digunakan dalam soal.

Soal nomor 4: Diketahui kubus ABCD.EFGH dengan panjang rusuk $8 \mathrm{~cm}$. Tentukan nilai kosinus sudut antara garis AG dan AC! Berikut ini merupakan beberapa jawaban siswa untuk soal nomor 4:

Pada gambar 4 siswa mampu menjawab soal secara tepat. Siswa mampu menyajikan pernyataan matematika secara tertulis, ini terlihat pada saat siswa menuliskan informasi yang ada pada soal ke dalam bentuk gambar kubus dengan jelas dan benar. Siswa juga mampu menyusun bukti untuk menentukan penyelesaian dari permasalahan yang diberikan, yaitu dengan mensubstitusikan panjang sisi samping dan panjang sisi miring dari segitiga siku-siku, dan pada akhirnya siswa dapat menarik kesimpulan dari pernyataan yang telah dibuat, yaitu menentukan nilai kosinus sudut antara garis AG dan garis AC dengan benar.
Soal nomor 5: Diketahui piramida Giza di Mesir berbentuk limas segi empat beraturan dengan panjang rusuk alas $230 \mathrm{~m}$ dan panjang rusuk tegak $219 \mathrm{~m}$. Tentukan jarak terdekat puncak piramida dengan lantai (alas) piramida! Berikut ini merupakan beberapa jawaban siswa untuk soal nomor 5 :

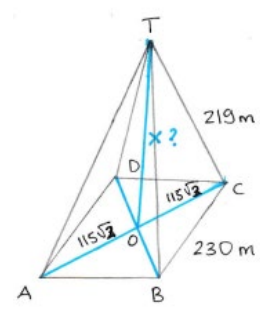

$$
x \ldots ? \quad \begin{aligned}
A C & =230 \sqrt{2} \\
O C & =\frac{230}{2} \sqrt{2} \\
& =115 \sqrt{2} \\
X & =\sqrt{219^{2}-(115 \sqrt{2})^{2}} \\
& =\sqrt{47961-26450} \\
& =\sqrt{21511} \mathrm{~cm}
\end{aligned}
$$

Gambar 10. Jawaban siswa soal nomor 5

Pada gambar 10 siswa mampu menyajikan informasi pada soal ke dalam bentuk gambar untuk memudahkan pengerjaan soal, siswa juga mampu melakukan manipulasi matematika, dalam menentukan nilai TO (jarak titik $T$ ke bidang $A B C D$ ). Siswa tidak menyatakan dugaan dalam menentukan rumus yang digunakan untuk menyelesaikan soal. Namun
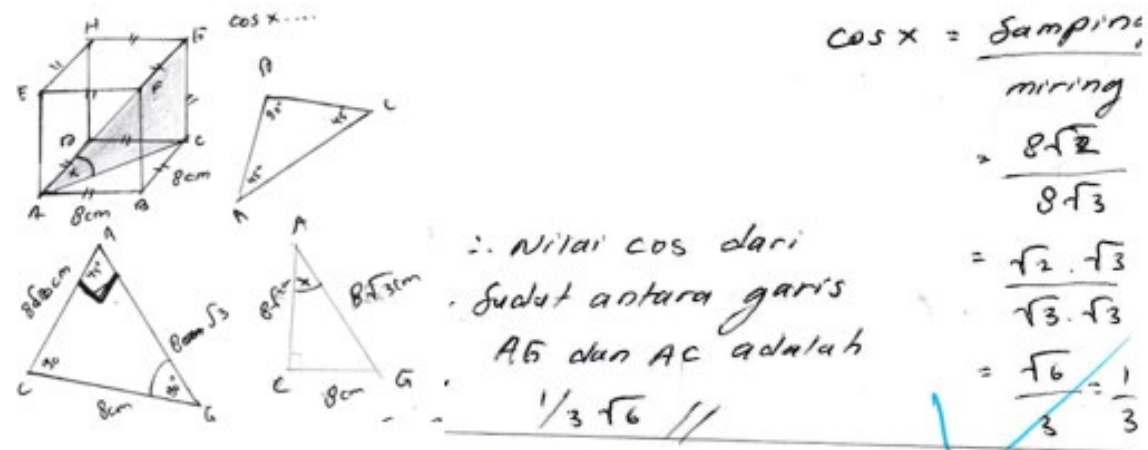

Gambar 9. Jawaban siswa soal nomor 4 
siswa mampu menyusun bukti-bukti dalam memperoleh kesimpulan yang benar dari soal nomor 5, walaupun dalam menyimpulkan hasil penyelesaikan siswa terkadang sering salah memberikan satuang panjang yang digunakan, siswa hanya fokus pada angka-angka pada soal.

\section{Pembahasan}

Berdasarkan data hasil penelitian dapat disampaikan bahwa kemampuan penalaran siswa SMA masuk dalam kategori cukup. Ada banyak faktor yang menjadi penyebab capaian ini. Dalam penelitian ini penyebab capaian penalaran tidak semuanya optimal aadalah karena proses berpikir logis, analitis, dan kritis yang kurang. Hal ini selaras dengan penelitian Bakoban dan Yunisah (2018). Untuk menguatkan kemampuan penalaran, siswa perlu dilatih berpikir logis dan kritis. Salah satu caranya adalah membiasakan diri untuk menyelesaikan masalah dengan membuat pertanyaan yang tepat, melihat fakta yang tersedia, membedakannya dengan asumsi, hingga menyelesaikan masalah tersebut dengan solusi yang kreatif juga sistematis. Membiasakan diri dalam berpikir matematis berarti membiasakan diri untuk mengkritisi data yang ditampilkan dalam kehidupan sehari-hari. Cara yang hampir serupa dilakukan juga oleh Abdullah (2016) dalam mebangun berpikir kritis matematis. Jika kemampuan berpikir kritis, logis, kreatif tersebut naik, tentu kemampuan penalaran siswa juga membaik.

\section{PENUTUP}

\section{Simpulan}

Dari hasil penelitian di SMA YPI Tunas Bangsa Palembang diperoleh nilai rata-rata kemampuan penalaran matematika siswa sebesar 66,11 yang tergolong rendah. Secara keseluruhan, indikator kemampuan penalaran matematika yang banyak dikuasai siswa adalah menyajikan pernyataan matematika dengan gambar dan tulisan, sedangkan indikator kemampuan penalaran matematika yang kurang dikuasai siswa adalah menarik kesimpulan dari suatu pernyataan.

\section{DAFTAR PUSTAKA}

Abdullah, I. H. (2016). Berpikir kritis matematik. DeltaPi: Jurnal Matematika dan Pendidikan Matematika, 2(1).

Anisa, W. N. (2015). Peningkatan kemampuan pemecahan masalah matematik melalui pembelajaran pendidikan matematika realistik untuk peserta didik SMP Negeri di Kabupaten Garut. JP $3 M$ (Jurnal Penelitian Pendidikan dan Pengajaran Matematika), 1(1), 73-82.

Bakoban, FI dan Yunisah, R. (2018). Isu-Isu tentang Rendahnya Kemampuan Penalaran Matematika Siswa Dalam Pembelajaran Matematika. Jurnal Pascasarjana UNIMED publish at Researchgate 1, 1-8.

Depdiknas. (2006). Kurikulum Standar Kompetensi Matematika Sekolah Menengah Atas dan Madrasah Aliyah. Jakarta: Depdiknas

Herman, T. (2007). Pembelajaran berbasis masalah untuk meningkatkan kemampuan berpikir matematis tingkat tinggi siswa sekolah menengah pertama. Educationist, 1(1), 47-56.

Indrawati, F. (2015). Pengaruh kemampuan numerik dan cara belajar terhadap prestasi belajar matematika. Formatif: Jurnal Ilmiah Pendidikan MIPA, 3(3).

Irawan, A. (2015). Pengaruh kecerdasan numerik dan penguasaan konsep matematika terhadap kemampuan berpikir kritik matematika. Formatif, 4(1).

Napitupulu, E. E., Suryadi, D., \& Kusumah, Y. S. (2016). Cultivating Upper Secondary Students' Mathematical Reasoning-Ability and Attitude towards Mathematics Through Problem-Based Learning. Journal on Mathematics Education, 7(2), 117-128.

PISA. (2012). Programme for International Student Assessment (PISA) Results from PSA 2012. Pisa 2012.

Safrida, L. N., As'ari, A. R., \& Sisworo, S. (2016). Pengembangan Perangkat Pembelajaran Berbasis Problem Solving Polya untuk Meningkatkan Kemampuan Penalaran Matematis Siswa Materi Peluang Kelas XI SMA. Jurnal Pendidikan: Teori, Penelitian, dan Pengembangan, 1(4), 583-591.

Safrina, K. (2014). Peningkatan kemampuan pemecahan masalah geometri melalui pembelajaran kooperatif berbasis teori van hiele. Jurnal Didaktik Matematika, 1(1).

Septianingsih, S. N. E., \& Fitriyani, H. (2018, January). Profil Kemampuan Penalaran Siswa Kelas Viii Smp Muhammadiyah 1 Gamping Tahun Ajaran 2015/2016 Ditinjau Dari Gaya Kognitif Reflektif-Impulsif. In Seminar Nasional Pendidikan Matematika Ahmad Dahlan (Vol. 1, pp. 217-223).

Shodiqin, A., \& Zuhri, M. S. (2018). Berpikir Impulsif Dalam Komunikasi Matematis Siswa Sekolah Menengah Pertama. Pythagoras: Jurnal Program Studi Pendidikan Matematika, 7(2).

Sulistiawati, S., Suryadi, D., \& Fatimah, S. (2015). Desain Didaktis Penalaran Matematis untuk Mengatasi Kesulitan Belajar Siswa SMP pada Luas dan Volume Limas. Kreano, Jurnal Matematika KreatifInovatif, 6(2), 135-146.

Suryadi, D. (2011). Pendidikan Matematika. Junal Pendidikan Matematika. 